University of Nebraska - Lincoln

DigitalCommons@University of Nebraska - Lincoln

Nebraska Cooperative Fish \& Wildlife Research Nebraska Cooperative Fish \& Wildlife Research Unit -- Staff Publications

\title{
Influence of the proximity and amount of human development and roads on the occurrence of the red imported fire ant in the lower Florida Keys
}

\author{
Elizabeth A. Forys \\ Eckerd College \\ Craig R. Allen \\ Clemson University, callen3@unl.edu \\ Daniel P. Wojcik \\ U.S. Department of Agriculture
}

Follow this and additional works at: https://digitalcommons.unl.edu/ncfwrustaff

Part of the Other Environmental Sciences Commons

Forys, Elizabeth A.; Allen, Craig R.; and Wojcik, Daniel P., "Influence of the proximity and amount of human development and roads on the occurrence of the red imported fire ant in the lower Florida Keys" (2002). Nebraska Cooperative Fish \& Wildlife Research Unit -- Staff Publications. 42.

https://digitalcommons.unl.edu/ncfwrustaff/42

This Article is brought to you for free and open access by the Nebraska Cooperative Fish \& Wildlife Research Unit at DigitalCommons@University of Nebraska - Lincoln. It has been accepted for inclusion in Nebraska Cooperative Fish \& Wildlife Research Unit -- Staff Publications by an authorized administrator of DigitalCommons@University of Nebraska - Lincoln. 


\title{
Influence of the proximity and amount of human development and roads on the occurrence of the red imported fire ant in the lower Florida Keys
}

\author{
Elizabeth A. Forys ${ }^{\mathrm{a}, *}$, Craig R. Allen ${ }^{\mathrm{b}}$, Daniel P. Wojcik \\ ${ }^{a}$ Environmental Studies, Natural Science Collegium, Eckerd College, 4200 54th Avenue South, St. Petersburg, FL 33711, USA \\ ${ }^{\mathrm{b}}$ U.S. Geological Survey, Biological Resources Division, South Carolina Cooperative Fish and Wildlife Research Unit, Clemson University, \\ Clemson, SC 29634, USA \\ ${ }^{\mathrm{c}}$ United States Department of Agriculture, ARS, CMAVE, Gainesville, FL 32604, USA
}

Received 3 July 2001; received in revised form 16 December 2001; accepted 24 January 2002

\begin{abstract}
We examined the influence of both the proximity and extent of human developments and paved roads on the presence of the predatory, non-indigenous, red imported fire ant (Solenopsis invicta). This species was inadvertently introduced into the United States at the port of Mobile, Alabama, around 1930 and rapidly spread to many southeastern states, including Florida. More recently, S. invicta colonized the Florida Keys, an area with a high proportion of rare and endemic vertebrate and invertebrate species. We placed bait transects in transitional salt-marsh, pineland, and hardwood hammocks on 13 of the lower Florida Keys and compared habitat type, the shortest distance of the bait transect to a development or road, and area of development and roads $50,70,100$, and $150 \mathrm{~m}$ around each bait transect for areas with and without red imported fire ants. Red imported fire ants were detected on 21 of the 80 transects and were equally abundant in all habitat types. While all of the development and road variables differed significantly between bait transects with and without red imported fire ants, transects that were closest to roads and that had the largest amount of development within a $150 \mathrm{~m}$ radii had the highest probability of presence of red imported fire ants. Recovery efforts for endangered species in areas invaded by red imported fire ants should include analyses of the cumulative impacts of roads and developments in areas near protected lands. (C) 2002 Elsevier Science Ltd. All rights reserved.
\end{abstract}

Keywords: Red imported fire ant; Solenopsis invicta; Lower Keys of Florida; Invasion biology; Non-indigenous species; Fragmentation

\section{Introduction}

Habitat destruction is the primary cause for the extinction of most terrestrial species (Bailie and Groombridge, 1996), but the impact of a human development or roads may be far greater than the immediate area of the destruction. One potential negative effect that roads and developments can have on native ecosystems is the increase in invasive, non-indigenous species in the surrounding area (Elton, 1958; Simberloff, 1981; Rejmánek, 1989). Human disturbance can increase non-indigenous species in two general ways: it can provide habitat with reduced native predators and competitors for a species that is a human commensal or

* Corresponding author. Tel.: + 1-727-864-7880; fax: + 1-727-8648382 .

E-mail address: forysea@eckerd.edu (E.A. Forys). an early succession species (Diamond and Veitch, 1981; Williamson, 1996) and/or the disturbance can act as a dispersal corridor, increasing the rate of invasion into undisturbed ecosystems (Tyser and Worley, 1992; Forman, 1995). Once established, some non-indigenous species have a dramatic negative influence on communities (Simberloff, 1981) and ecosystems (Vitousek, 1990; Vitousek et al., 1996).

One of the most destructive non-indigenous species is the red imported fire ant (Solenopsis invicta). Red imported fire ants were inadvertently introduced into the United States at the port of Mobile, Alabama, around 1930 from South America and rapidly spread to many southeastern states, including Florida (Vinson and Sorensen, 1986). All counties in Florida were infested by 1976 (Callcott and Collins, 1996). The climate in the southeastern United States is similar to the climate in parts of Africa, Asia, and Australia, indicating that if 
an introduction were to occur in these areas that it might be successful.

Solenopsis invicta is known to prey on or compete with a wide range of invertebrates (Porter and Savignano, 1990) and vertebrates (Allen et al., 1994). Solenopsis invicta is attracted to mucous (Vinson and Sorensen, 1986), making newborn mammals, recently pipped birds and herpetofauna, and species that leave mucous trails particularly vulnerable to predation. The larval and pupal stages of invertebrates are at risk because of their inability to escape from fire ant attacks. Vertebrate species that have been predated on by red imported fire ants include gopher tortoises (Gopherus polyphemus, Landers et al., 1980), loggerhead turtles (Caretta caretta, Moulis, 1997), eastern cottontails (Sylvilagus floridanus, Hill, 1970), small mammals (Smith et al., 1990; Killion and Grant, 1993), and whitetailed deer (Odocoileus virginianus, Allen et al., 1997). In addition, Solenopsis invicta, outcompetes native ants and reduces diversity in many insect communities (Porter and Savignano, 1990).

More recently, Solenopsis invicta colonized the lower Florida Keys, a subtropical area with a high proportion of rare and endemic vertebrate and invertebrate species. Solenopsis invicta is a voracious predator that could have a large negative impact on many of the species in the lower Keys, as well as overall biodiversity. The lower Florida Keys are the terminal portion of an archipelago of islands extending westward from the mainland of Florida (Fig. 1). The lower Keys also are a place where substantial habitat destruction and fragmentation have recently occurred (Davis and Odgen, 1994). Primarily due to this habitat destruction, much of the lower Keys' fauna is endangered (Humphrey, 1992). In an attempt to preserve the diversity of the lower Keys, much of this land has been purchased by federal, state, and private conservation organizations. Despite this protection, populations of several species remain low (Humphrey, 1992; Moler, 1992). One possible contributing factor to the low abundances of some of these species may be mortality caused by Solenopsis invicta.

Previous studies have shown that Solenopsis invicta favors open and semi-open habitats (including disturbed areas), and generally forages when soil temperatures are between 22 and $36^{\circ} \mathrm{C}$ at a depth of $2 \mathrm{~cm}$ (Porter and Tschinkel, 1987); these conditions are found throughout the Lower Keys. Despite this, Solenopsis invicta was not found in Wilson's 1958 collecting trip to Key West and Big Pine Key (Wilson, 1964). Deyrup and colleagues only found Solenopsis invicta in highly disturbed areas (e.g. parking lots, roadsides) on two of the main lower Keys (Key West, Saddlebunch) despite numerous collecting trips from 1982 to 1987 (Deyrup et al., 1988). Porter (1992) surveyed the roadsides of seven of the lower Keys and only found Solenopsis invicta on one key (Stock Island). While red imported fire ants appear to be able to invade and establish populations in disturbed habitats in the Florida Keys (e.g. developments

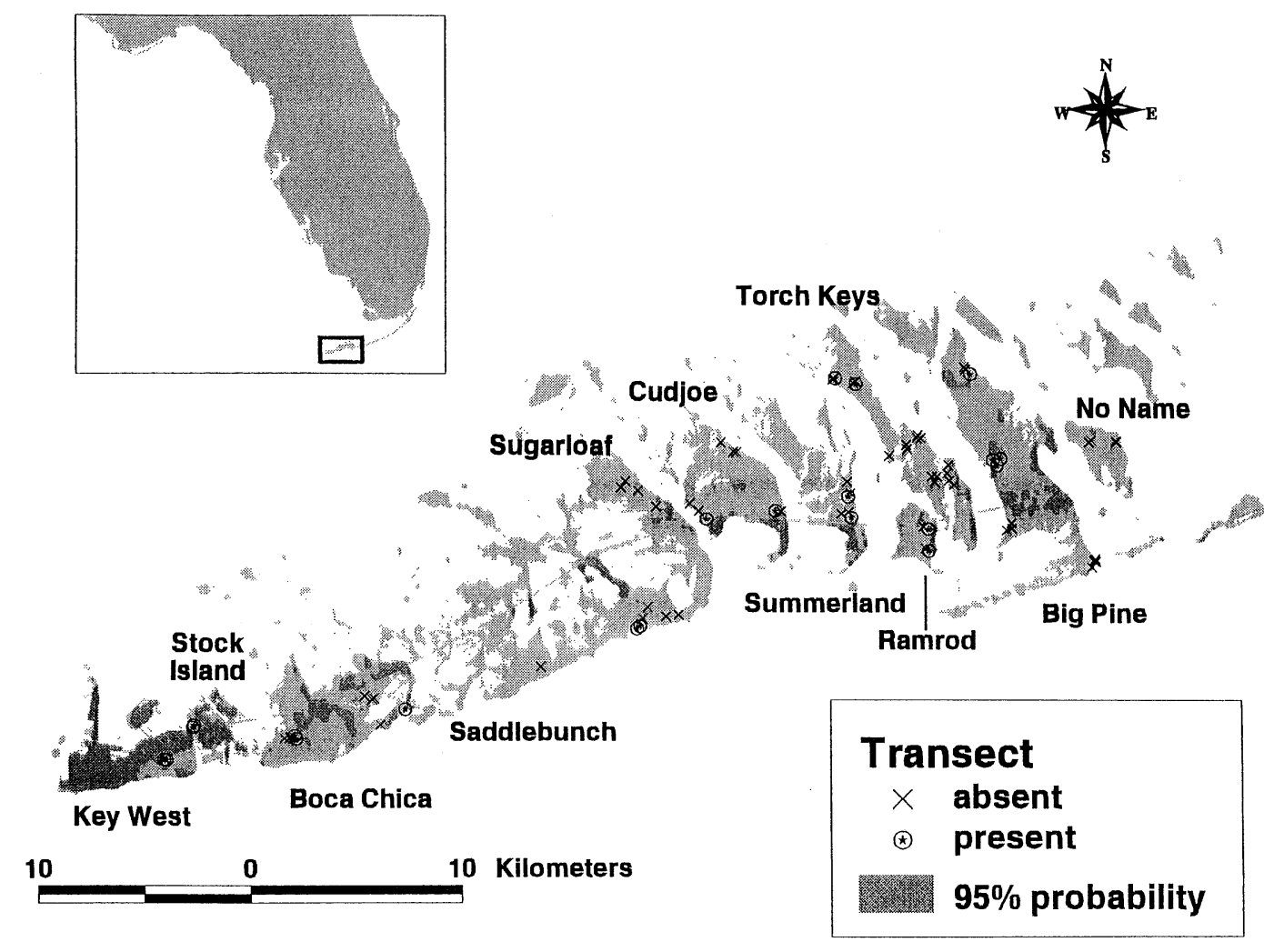

Fig. 1. Location of the lower Florida Keys, bait transect locations, and the predicted distribution of Solenopsis invicta (95\% probability). 
and roadsides), it is not known if the species has the ability to invade undisturbed habitat. In addition, the effects of additional developments and roads on presence of Solenopsis invicta in the vicinity of protected lands has never been explored.

The purpose of this study was to examine the influence of development and roads on the presence of Solenopsis invicta in undisturbed preserved habitat in the Florida Keys. Specifically, we examined both the proximity of roads and development and the amount of area disturbed by roads or development on presence of Solenopsis invicta.

\section{Methods}

\subsection{Distribution and abundance of red imported fire ants}

We collected data on the presence of Solenopsis invicta on all of the lower Keys that are reachable by road and have some development. Publicly owned habitat patches of pinelands, hardwood hammocks, and transitional salt-marsh that were $>0.10$ ha were sampled. Some of the smaller, lower-elevation keys lacked these three habitat types, so as many habitats were surveyed as possible. Pinelands are dominated by south Florida slash pine (Pinus elliottii var. densa) overstory and saw palmetto (Serenoa repens) understory. Hardwood hammocks are closed-canopy broad-leaved forests that have a high diversity ( $>150$ species) of both evergreen and semi-evergreen tropical tree species. Transitional salt-marsh typically occurs at 3-5 m above sea-level between mangroves and the upland hardwood hammocks. The dominant tree species is buttonwood (Conocarpus erectus) and the understory is comprised of marsh grasses and sedges.

Ant bait transects were placed on preserved lands using randomly chosen Universal Transverse Mercator coordinates within the habitat patch as the starting point and a random number table to determine the orientation of the transect. While ant mound counting is an acceptable method of estimating fire ant presence and abundance in central Florida and north to Virginia, in the Florida Keys red imported fire ants colonies often do not form mounds, but exist in cracks and fissures in the limestone substrate.

Thirty-five of the transects were placed in hardwood hammocks, 34 were placed in transitional salt-marsh and 10 were in pinelands. Each transect was $90 \mathrm{~m}$ long and consisted of 10 stations of paired baits (one honey, one meat $45-60 \mathrm{~cm}$ apart) placed on the ground, spaced $10 \mathrm{~m}$ apart (Wojcik, 1994). Each bait transect was sampled once during a 2-week period from 15 to 31 July 1996 in the morning (07:00-10:00 hours) or the afternoon (16:00-19:00 hours) when temperatures were favorable for fire ant foraging. After placement, baits were left out for $1.5 \mathrm{~h}$ to attract ants and then were collected and placed in cups, frozen, and transported to the USDA, ARS, Imported Fire Ant Laboratory (Gainesville, FL). In the laboratory ants were picked from the bait, placed in alcohol, and identified to species.

\subsection{Data analyses}

A logistic analysis (a logistic regression that incorporates class variables, SYSTAT, 1992) was conducted using the presence or absence of red imported fire ants at a transect as the dependent variable and the following as independent variables:

- habitat type;

- the euclidean (shortest) distance of the closest portion of the bait transect to a development;

- area of development 50,75, 100, $150 \mathrm{~m}$ around each bait transect;

- the euclidean (shortest) distance of the closest portion of the bait transect to a paved road; and

- area of roads $50,75,100,150 \mathrm{~m}$ around each bait transect.

We measured independent variables using habitat and road data sets analyzed using geographic information system (GIS) software (ARC/INFO, 1990). Habitat data (including types of human developments) came from the Advanced Identification project mapping coverages (ARC/INFO data sets) provided by the Environmental Protection Agency (EPA, Region IV, Atlanta). These vector-based coverages were created by digitizing habitats based on photo interpretation and ground-truthing. The minimum resolution was approximately 0.10 ha. To estimate the influence of human development, we selected all areas in the habitat coverage that had been classified as being "developed" by the habitat map. Developed areas included buildings, parking lots, and highly disturbed yards $>0.10$ ha. In ARC/INFO we created coverages that estimated the euclidean (shortest) distance of a transect to a development. We also used GRID to calculate the sum of development within an oval-sized neighborhood of 50 , $75,100,150 \mathrm{~m}$ radii around each transect in the lower Keys and to produce a raster-based coverage of these values. We did not examine neighborhoods $>150 \mathrm{~m}$ because many of these would include a large proportion of water. We repeated this process for the roads coverage. Road data came from Florida Department of Transportation vector-based coverages. To prepare these vector-based map coverages for analysis we converted them to raster-based maps using the GRID module of ARC/INFO. We used a $10 \times 10 \mathrm{~m}$ sized cell for all raster maps.

Our dependent variable was the presence or absence of Solenopsis invicta at the bait stations on a linear 
transect. We classified a transect as having Solenopsis invicta if it was detected at one of the 10 bait stations. All transects were mapped using a GPS (global positioning system) and the locations were converted to a GIS data layer.

We reduced the inter-correlated variables prior to multivariate analyses. The variable with the highest between-group significance was retained and used in the model. The best model was used to create a grid of predicted values for the dependent variable at each cell throughout the lower Keys. If a variable was not normally distributed we used a logarithmic transformation. The retained and transformed variables were entered into a stepwise logistic analysis to derive a multivariate model that would predict the presence or absence of red imported fire ants. The resulting models were evaluated using goodness-of-fit tests based on maximum likelihood estimates and how accurately they classified red imported fire ant presence or absence. All of the variables were compared using a $t$-test if the data was normally distributed and the variances were equal and a Mann-Whitney rank sum test if otherwise.

\section{Results}

We identified Solenopsis invicta from 21 of 80 transects on 9 of the 13 lower Keys. On the transects where Solenopsis invicta was detected, the average number of bait stations with Solenopsis invicta was $5.4(\mathrm{SD}=2.4)$ and the range was from 3 to 10 (out of 10 stations total). We identified 48 species of ants and a total of 287,180 individuals from the 80 transects. Solenopsis invicta was the seventh most abundant species, comprising nearly $8 \%(22,775)$ of the total ants counted.

Solenopsis invicta was present at $29 \%$ of the transects in the transitional salt-marsh, $30 \%$ of the pinelands transects, and $23 \%$ of the hardwood hammock transects. The proportion of transects with $S$. invicta did not vary significantly by habitat type $\left(\chi^{2}=0.262, P<0.88\right.$, $\mathrm{df}=2$ ).

None of the development variables was significantly correlated with the road variables $(r<0.4, P>0.05)$, but all of the development variables and all of the road variables were significantly inter-correlated with each other $(r>0.4, P<0.05)$. None of the independent variables were normally distributed, therefore a MannWhitney rank sum test was conducted comparing the median values for transects that had Solenopsis invicta present to transects where Solenopsis invicta was absent. All of the road and development variables significantly $(P<0.05)$ differed between transects with Solenopsis invicta absent and present (Table 1). The euclidean distance to roads was the most significant roads-related variable. Transects closest to roads were the most likely to have Solenopsis invicta. The amount of development at the largest scale analyzed $(150 \mathrm{~m}$ around a bait transect) was the most significant development-related variable. The more development, the more likely red imported fire ants were collected in the bait transect.

These two variables (euclidean distance to roads and development $150 \mathrm{~m}$ around the transect) were transformed and used as independent variables for our logistic analysis. The model converged on one significant model based on the function:

$\operatorname{logit}(P)=2.543-0.034 R+0.044 D$

where $P$ is the probability of presence of Solenopsis invicta, $R$ is the euclidean distance to a road, and $D$ is the amount of development $150 \mathrm{~m}$ around a transect (Fig. 1). The goodness-of-fit test that compared the two variable model with a model with just the constant was significant $\left(\chi^{2}=28.88, P<0.0001, \mathrm{df}=2\right)$. Classification accuracy of the model was high when predicting which bait transects would not have red imported fire ants (51 correct, eight incorrect). The classification accuracy of transects with red imported fire ants was not as high (11 correct, 10 incorrect).

\section{Discussion}

\subsection{Distribution of Solenopsis invicta}

During the past 10 years, Solenopsis invicta has dramatically expanded its distribution in the lower Florida Keys from only highly disturbed areas on a few of the most urbanized keys (Deyrup et al., 1988; Porter, 1992) to all of the major habitat types on most of the lower Keys. The colonization of native habitats by Solenopsis invicta appears to be facilitated the greatest by close proximity of roads and by large developments. However, the low classification accuracy of the logistic analysis indicates that there may be additional factors that determine presence or absence of red imported fire ants. In addition, the invasion of red imported fire ants appears to be ongoing and the model only predicts the current distribution.

Previous studies of aggressive, non-indigenous ants have found that roads and developments increase nonnative ants, but these studies were conducted on smaller spatial scales. Stiles and Jones (1998) determined that Solenopsis invicta mound density was higher in open dirt and paved roads than powerline cuts and closed-canopy dirt roads in coastal South Carolina. They also noted that within the closed-canopy forest, there were more mounds closer to the edge of the roads than $20 \mathrm{~m}$ into the forest. Development was not examined in their study.

Studies of the Argentine ant (Linepithema humile), an aggressive non-indigenous ant, in southern California 
Table 1

Comparison of the median values (not transformed) of independent variables used to determine Solenopsis invicta presence or absence on transects in the Lower Keys of Florida ${ }^{a}$

\begin{tabular}{lll}
\hline Variable & Solenopsis invicta absent & Solenopsis invicta present \\
\hline Euclidean distance to development & $1273 \mathrm{~m}$ & $300 \mathrm{~m} * *$ \\
Development in a $50 \mathrm{~m}$ neighborhood & 0 & $1900 \mathrm{~m}^{2} *$ \\
Development in a $75 \mathrm{~m}$ neighborhood & 0 & $4500 \mathrm{~m}^{2} * *$ \\
Development in a $100 \mathrm{~m}$ neighborhood & 0 & $8900 \mathrm{~m}^{2} * * *$ \\
Development in a $150 \mathrm{~m}$ neighborhood & $2000 \mathrm{~m}^{2}$ & $19,400 \mathrm{~m}^{2} * * * *$ \\
Euclidean distance to roads & $2240 \mathrm{~m}$ & $900 \mathrm{~m}^{2} * * *$ \\
Roads in a $50 \mathrm{~m}$ neighborhood & 0 & $900 \mathrm{~m}^{2} *$ \\
Roads in a $75 \mathrm{~m}$ neighborhood & 0 & $1400 \mathrm{~m}^{2} *$ \\
Roads in a $100 \mathrm{~m}$ neighborhood & $900 \mathrm{~m}^{2}$ & $4600 \mathrm{~m}^{2} * *$ \\
Roads in a $150 \mathrm{~m}$ neighborhood & $3000 \mathrm{~m}^{2}$ & $8900 \mathrm{~m}^{2} * * *$ \\
\hline
\end{tabular}

a Mann-Whitney $U$ test were performed.

$* P<0.05$.

** $P<0.01$.

$* * * \quad P<0.001$.

**** $P<0.0001$.

(Suarez et al., 1998) and northern California (Human et al., 1998) found that these ants were more likely to be present near the edges of preserves. Preserve edges were apparently closer to both roads and development.

Road construction was found to have a profound effect on the long-term alpha diversity of ants in Western Australia (Majer and Beeston, 1996) and on the ecologically dominant ant species in South Africa (Samways et al., 1997). Samways et al. (1997) hypothesized that aggressive ant species such as Pheidole megacephala may have had a competitive advantage on roadsides because of the availability of road kills for food.

In the Florida Keys, it appears that roads and development facilitate colonization both by providing optimal Solenopsis invicta habitat and by providing corridors into native habitat. Solenopsis invicta probably invade disturbed areas (developed areas and roads) in several ways: (1) natural mating flights which may occur throughout the year in southern Florida, (2) movement of colonies with mated queens in nursery stock or construction fill, and (3) transportation of newly mated queens that land in vehicles and are transported to new areas (Vinson and Sorensen, 1986). Invasion of areas lacking native cover, and thus fauna, is probably facilitated by the lack of competitors and predators. Such areas exhibit higher reflectivity and are thought to be more attractive to newly mated queens.

While close proximity of an undisturbed area to a development did appear to increase the probability of invasion, the amount of development at the largest scale investigated $(150 \mathrm{~m}$ around the transect) was the most significant variable. Twenty-seven percent (16) of the transects in undisturbed areas that were $\leqslant 10 \mathrm{~m}$ from a development did not have Solenopsis invicta, but these areas had significantly less development $150 \mathrm{~m}$ around their transects than the 10 transects that had Solenopsis invicta $(t=-2.25, P=0.03, \mathrm{df}=24.0)$ and were $\leqslant 10 \mathrm{~m}$ from a development.

The shortest distance from a transect to a road was the most significant roads-related variable. Several of the transects with Solenopsis invicta were surrounded by relatively little development but were relatively close to a single road. While Solenopsis invicta may forage up to $50 \mathrm{~m}$ from a colony that exists on the road-side, fire ants at these transects were found at baits $>50 \mathrm{~m}$ from the road indicating they came from a colony within the intact habitat.

\subsection{Conservation implications}

Even a single road traversing through preserved land or the expansion of an existing development near a refuge may increase the probability of invasion by Solenopsis invicta. In the lower Florida Keys there are at least nine federally endangered endemics which occur in upland habitats such as transitional salt-marsh, pinelands, and hardwood hammocks and may be negatively impacted by red imported fire ants. All of these species may be negatively effected by Solenopsis invicta either through direct predation or indirect effects. Indirect effects include reduction in survival and weight gain resulting from envenomization, behavioral changes in the impacted species, changes in foraging patterns, changes in habitat use and reduce food availability. Indirect effects may be more important than direct predation, but are more difficult to study (Allen et al., 1998). These nine species include two mammals [Lower Keys marsh rabbit (Sylvilagus palustris hefneri), Key deer (Odocoileus virginianus clavium)], four reptiles [striped mud turtle (Kinosternon baurii), Big Pine Key ringneck snake (Diadophis punctatus acricus), Florida brown snake (Storeria dekayi victa), red rat snake (Elaphe guttata guttata)], and three invertebrates 
[Florida tree snail (Liguus fasciatus), Florida Keys tree snail (Orthalicus reses nesodryas), Stock Island tree snail (Orthalicus reses reses)].

Current recovery efforts for these species have been aimed at protecting the habitat where these species currently occur (US Fish and Wildlife Service, 1999). Little effort has been made to reduce new roads and development in surrounding areas. Recovery goals for these species should include research to examine the effect of red imported fire ants. If the direct and indirect effects of red imported fire ants are found to be significant, the cumulative impacts of roads and development in the vicinity of endangered species habitat should be considered when permits are being evaluated.

\section{Acknowledgements}

We would like to thank The Nature Conservancy, Florida Department of Environmental Protection, and the United States Fish and Wildlife Service for permission to sample ants on their lands. J. Sullenger, B. Mayfield, A. Quistorff, and J. Hosford helped collect, sort, and identify ants. M. Pratt provided assistance with data entry and analysis. The Florida Game and Fresh Water Fish Commission provided funding for this project.

\section{References}

Allen, C.R., Demaris, S., Lutz, R.S., 1994. Red imported fire ant impact on wildlife: an overview. Texas Journal of Science 46, 51-59.

Allen, C.R., Demarais, S., Lutz, R.S., 1997. Effects of red imported fire ants on recruitment of white-tailed deer fawns. Journal of Wildlife Management 61, 911-916.

Allen, C.R., Lutz, R.S., Demarais, S., 1998. Ecological effects of the invasive nonindigenous ant, Solenopsis invicta, on native vertebrates: the wheels on the bus. Transactions of the 63rd North American Wildlife and Natural Resource Conference 63, 56-65.

ARC/INFO, Environmental Systems Research Institute, 1990. ARC/ info User's Guide, Environmental Systems Research Institute, Redlands, CA.

Bailie, J., Groombridge, B., 1996. 1996 IUCN Red List of Threatened Animals. World Conservation Union (IUCN), Gland, Switzerland.

Callcott, A.M.A., Collins, H.L., 1996. Invasion and range expansion of red imported fire ant (Hymenoptera: Formicidae) in North America from 1918-1995. Florida Entomologist 79, 240-251.

Davis, S.M., Odgen, J.C., 1994. Everglades: the Ecosystem and its Restoration. St. Lucie Press, Delray Beach, FL.

Deyrup, M.A., Carlin, N., Trager, J., Umphrey, G., 1988. A review of the ants of the Florida keys. Florida Entomologist 71, 163-176.

Diamond, J.M., Veitch, C.R., 1981. Extinctions and introductions in the New Zealand avifauna: cause and effect? Science 211, 499-501.

Elton, C.S., 1958. The Ecology of Invasions by Animals and Plants. Methuen, London.

Forman, R.T.T., 1995. Land Mosaics: the Ecology of Landscapes and Regions. Cambridge University Press, Cambridge, England.

Hill, E.P., 1970. Observations of imported fire ant predation on nestling cottontails. Proceedings of the Southeast. Association of the Game and Fish Commission 23, 171-181.
Human, K.G., Weiss, S., Weiss, A., Sandler, B., Gordon, D.M., 1998. Effects of abiotic factors on the distribution and activity of the invasive argentine ant (Hymenoptera: Formidicidae). Environmental Entomology 27, 822-833.

Humphrey, S.R., 1992. Rare and Endangered Biota of Florida. Vol. 1: Mammals. University Press of Florida, Gainesville, FL.

Killion, M.J., Grant, W.E., 1993. Scale effects in assessing the impact of imported fire ants on small mammals. Southwestern Naturalist 38, 393-396.

Landers, J.L., Garner, J.A., McRae, W.A., 1980. Reproduction of gopher tortoises (Gopherus polyphemus) in southwestern Georgia. Herptologica 36, 353-361.

Majer, J.D., Beeston, G., 1996. The biodiversity integrity index: an illustration using ants in Western Australia. Conservation Biology 10, 65-73.

Moler, P.E., 1992. Rare and endangered biota of Florida. Vol. III. Amphibians and Reptiles. University Press of Florida, Gainesville, FL.

Moulis, R.A., 1997. Predation by the imported fire ant (Solenopsis invicta) on loggerhead sea turtle (Caretta caretta) nests on Wassaw National Wildlife Refuge, Georgia. Chelonian Conservation Biology 2, 105-106.

Porter, S.D., 1992. Frequency and distribution of polygyne fire ants (Hymenoptera: Formicidae) in Florida. Florida Entomologist 75, 248-257.

Porter, S.D., Tschinkel, W.R., 1987. Foraging in Solenopsis invicta (Hymenoptera: Formicidae): effects of weather and season. Environmental Entomology 16, 802-808.

Porter, S.D., Savignano, D.A., 1990. Invasion of polygyne fire ants decimates native ants and disrupts arthropod community. Ecology 71, 2095-2106.

Rejmánek, M., 1989. Invasibility of plant communities. In: Drake, J.A., Mooney, H.A., di Castri, F., Groves, R.H., Kruger, F.J., Rejmánek, M., Williamson, M. (Eds.), Biological Invasions, a Global Perspective. John Wiley, Chichester, England, pp. 369-388.

Samways, M.J., Osborn, R., Carliel, F., 1997. Effect of a highway on ant (Hymenoptera: Formicidae) species composition and abundance, with a recommendation for roadside verge width. Biodiversity and Conservation 6, 903-913.

Simberloff, D.E., 1981. Community effects of introduced species. In: Nitecki, M.H. (Ed.), Biotic Crises in Ecological and Evolutionary Time. Academic Press, New York, pp. 53-81.

Smith, T.S., Smith, S.A., Schmidly, D.J., 1990. Impact of fire ant (Solenopsis invicta) density on northern pygmy mice (Baiomys taylori). Southwestern Naturalist 35, 158-162.

Stiles, J.H., Jones, R.H., 1998. Distribution of the red imported fire ant, Solenopsis invicta, in road and powerline habitats. Landscape Ecology 13, 335-346.

Suarez, A.V., Bolger, D.T., Case, T.J., 1998. Effects of fragmentation and invasion on native ant communities in coastal southern California. Ecology 79, 2041-2056.

SYSTAT, 1992. SYSTAT for Windows: Statistics. Version 5. SYSTAT, Evanston, IL.

Tyser, R.W., Worley, C.A., 1992. Alien flora in grasslands adjacent to road and trail corridors in Glacier National Park, Montana (USA). Conservation Biology 6, 253-262.

US Fish and Wildlife Service, 1999. South Florida Multi-Species Recovery Plan. Atlanta, Georgia.

Vinson, S.B., Sorensen, A.A., 1986. Imported Fire Ants: Life History and Impact. Texas Department of Agriculture, Austin, TX.

Vitousek, P.M., 1990. Biological invasions and ecosystem processes: towards an integration of population biology and ecosystem studies. Oikos 57, 7-13.

Vitousek, P.M., D’Antonio, C.M., Loope, L.L., Westbrooks, R., 1996. Biological invasions as global environmental change. American Scientist 84, 468-478. 
Williamson, M., 1996. Biological Invasions. Chapman and Hall, London.

Wilson, E.O., 1964. The ants of the Florida Keys. Breviora 210, $1-14$.
Wojcik, D.P., 1994. Impact of the red imported fire ant on native ant species in Florida. In: Williams, D.F. (Ed.), Exotic Ants: Biology, Impact, and Control of Introduced Species. Westview Press, Boulder, CO, pp. 269-281. 